\title{
Tri-nucleotide receptors play a critical role in epithelial cell wound repair
}

\author{
Ilene Weinger ${ }^{1}$, Veronica E. Klepeis ${ }^{2}$ \& Vickery Trinkaus-Randall ${ }^{1,3,4}$ \\ ${ }^{1}$ Department of Biochemistry, Boston University School of Medicine, Boston, Massachusetts, USA; ${ }^{2}$ Department of \\ Pathology, Boston University School of Medicine, Boston, Massachusetts, USA; ${ }^{3}$ Department of Ophthalmology, Boston \\ University School of Medicine, Boston, Massachusetts, USA
}

Received 1 December 2004; accepted in revised form 1 April 2005

Key words: $\mathrm{Ca}^{2+}$ imaging, epidermal growth factor, epithelium, migration, wound repair

\begin{abstract}
The cornea plays a major role in the refraction of light to the retina. Therefore, the integrity and transparency of the corneal epithelium are critical to vision. Following injury, a combination of rapid signal transduction events and longterm cell migration are essential for wound closure. We have demonstrated previously that injury resulted in the release of nucleotides that induce the propagation of a $\mathrm{Ca}^{2+}$ wave to neighboring cells. This suggests that nucleotides and their receptors are critical components of wound healing. Epidermal growth factor (EGF) and integrins also have been shown to play a role in injury. In this study, we demonstrate that pretreatment of cells with ATP and UTP inhibited the immediate wound response, while BzATP, ADP, and UDP did not affect this response. Tri-nucleotide pretreatment also reduced the EGF induced $\mathrm{Ca}^{2+}$ response. Additionally, lower $\mathrm{EC}_{50}$ concentrations of ATP and UTP triggered migration of cells that was enhanced further with EGF and was inhibited by the tripeptide, RGD. Results indicate that the desensitization induced by ATP and UTP was specific. While ADP and UDP cause a homologous desensitization of their own signal, they did not cause an inhibition of the wound response nor does BzATP. Neither $\mathrm{Ca}^{2+}$ wave propagation nor cell migration occurred in response to $\beta, \gamma$-MeATP. Together these results lead us to hypothesize that corneal epithelial wound repair is mediated by both $\mathrm{P}_{2} \mathrm{Y}_{2}$ and $\mathrm{P} 2 \mathrm{Y}_{4}$ receptors.
\end{abstract}

Abbreviations: BAPTA - 1,2-bis(o-aminophenoxy)ethane- $N, N, N^{\prime}, N^{\prime}$-tetraacetic acid; DAG - diacylglycerol; EGF - epidermal growth factor; EGFR - epidermal growth factor receptors; GPCR - G-protein coupled receptors; HB-EGF - pro-heparin binding EGF; HCE-T-human corneal epithelial cells transformed; $\mathrm{IP}_{3}$-phosphoinositol tri-phosphate; MMP-matrix metalloproteases; PBS - phosphate buffered saline; $\mathrm{PIP}_{2}$ - phosphatidylinositol 4,5-bisphosphate; PKC-Protein kinase C; PLC - phospholipase C; RGD - arginine-glycine-aspartic acid; RGE - arginine-glycine-glutamic acid

\section{Introduction}

Wound healing is a series of complex biological responses requiring cytoskeletal and extracellular matrix remodeling, signal cascades, and gene regulation. Initial and long-term signals after injury are communicated to the cells and promote wound healing. These signals and events must be understood to advance our knowledge of normal wound repair. Investigators have demonstrated that nucleotides are released from cells by mechanical stimulation, ligand binding, exocytotic release, or injury [1-5] Nucleotide stimulation can also lead to an increase in intracellular calcium. The increase in cytosolic calcium can be generated via activation of purinergic ( $\mathrm{P} 2 \mathrm{Y}$ or $\mathrm{P} 2 \mathrm{X})$ receptors through distinct mechanisms. In addition, purinergic receptors can promote cell migration, a critical component

Correspondence to: Dr Vickery Trinkaus-Randall, Boston University School of Medicine, 80 East Concord Street, L904, Boston, MA 02118 USA. Tel: +1-617-638-5099; Fax: +1-617-638-5337; E-mail: vickery@bu.edu of wound repair. The exact role and identity of the various receptors and their importance in different systems has yet to be elucidated.

Nucleotides have been shown to accelerate wound closure [6]. Nucleotides can act as a chemotactic stimulus for cell migration in many cell types including corneal epithelial [7], arterial smooth muscle [8], microvascular endothelial [9], and immature dendritic cells [10]. P2 receptors also have been shown to play a role in repair after ischemia and renal tubular epithelial wound healing [11, 12]. Previously, we demonstrated that ATP plays a critical role in intercellular communication following mechanical injury. ATP induced cell migration, and Reactive Blue-2, a P2 antagonist, inhibited wound closure [7]. In addition, nucleotides induced calcium waves and phosphorylation of paxillin $\left(\mathrm{pY}^{118}\right)$ and ERK1/2 in a transient manner [7, 13]. Furthermore, neither occurred in the presence of $\beta, \gamma$-MeATP $[7,13]$. Our goal is to determine how epithelial cells respond to nucleotides in order to understand the events that occur after injury. 
$\mathrm{P} 2 \mathrm{Y}$ and $\mathrm{P} 2 \mathrm{X}$ receptors are expressed in a number of cell types. As G-protein coupled receptors (GPCR), P2Y receptors are seven pass transmembrane receptors coupled to heterotrimeric G-proteins (review in [14]). P2Y receptors couple to $\mathrm{G} \alpha_{\mathrm{q}}$ and activate phospholipase C $\beta$ (PLC $\beta$ ), which cleaves phosphatidylinositol 4,5-bisphosphate $\left(\mathrm{PIP}_{2}\right)$ to diacylglycerol (DAG) and phosphoinositol tri-phosphate $\left(\mathrm{IP}_{3}\right) . \mathrm{IP}_{3}$ binds to $\mathrm{Ca}^{2+}$ channels on the endoplasmic reticulum and causes an increase in intracellular $\mathrm{Ca}^{2+}$. This family of receptors consists of eight members: $\mathrm{P} 2 \mathrm{Y}_{1}, \mathrm{P} 2 \mathrm{Y}_{2}$, $\mathrm{P} 2 \mathrm{Y}_{4}, \mathrm{P} 2 \mathrm{Y}_{6}, \mathrm{P} 2 \mathrm{Y}_{11}, \mathrm{P} 2 \mathrm{Y}_{12}, \mathrm{P} 2 \mathrm{Y}_{13}$, and $\mathrm{P} 2 \mathrm{Y}_{14}$. $\mathrm{P} 2 \mathrm{X}$ receptors are ligand gated ion channels that open upon agonist binding allowing extracellular calcium to enter the cell. This family of receptors has seven members: $\mathrm{P} 2 \mathrm{X}_{1-7}$. Each receptor has a specific agonist potency profile for different nucleotides with some showing preference for a specific nucleotide and others preferentially responding to tri-nucleotides or adenine based nucleotides [15]. We have shown that corneal epithelial cells express a number of P2YR subtypes [7], and an intracellular $\mathrm{Ca}^{2+}$ increase is seen in response to both nucleotides and injury [5].

Epidermal growth factor receptor (EGFR) also plays an important role in injury response. The EGFR family has four receptor family members, ErbB1-4. These receptors can form both homo- and hetero-dimers when stimulated by the epidermal growth factor (EGF) or other ligands [16]. The EGFR becomes activated upon injury, and inhibition of ErbB phosphorylation limits proper wound closure in vitro [7]. EGF itself promotes cell migration and wound healing in vivo [17] and can up-regulate integrin expression [18]. Gross mechanical injury induces a $\mathrm{Ca}^{2+}$ wave that propagates out from the wound site. EGF has been shown to increase the intensity of the $\mathrm{Ca}^{2+}$ wave but is not required for propagation [5]. Recently, growth factor receptors and GPCRs have been demonstrated to participate in cross talk connecting signaling pathways through transactivation, which can occur via enhancement or downregulation of downstream signal cascades [19]. In addition, specific P2 receptors can associate with other signaling proteins. For example, $\mathrm{P}_{2} \mathrm{Y}_{2}$ has an arginine-glycineaspartic acid (RGD) domain on its first extracellular loop that can associate with integrins [20]. Currently, no other P2Y receptor has an identified RGD domain that interacts with integrins. In addition, this RGD domain promotes signaling and interactions with epidermal growth factor receptors (EGFR) [21].

Our goal is to determine if specific $\mathrm{P} 2$ receptors play a role in the injury response and wound healing in the cornea. Improper wound repair can alter refraction of light, one of the major roles of the cornea. Immediately after injury, corneal epithelial cells display an intracellular $\mathrm{Ca}^{2+}$ wave that propagates from the site of injury to neighboring cells [5]. This wave does not propagate via gap junctions but is mediated by the release of extracellular nucleotides activating P2Y receptors that lead to activation of intracellular signaling pathways such as ERK1/2 [13]. We hypothesize that injury induces an immediate localized event that stimulates later events such as release of growth factors and long-term signals.
In this paper, we provide evidence that specific subtypes of purinergic receptors regulate the injury response. Pretreatment of cells with ATP and UTP inhibited the propagation of the injury induced $\mathrm{Ca}^{2+}$ wave while BzATP, ADP, and UDP did not participate in the desensitization. In addition, pre-stimulation with tri-nucleotides, but not BzATP or di-nucleotides, resulted in a decrease in the intracellular $\mathrm{Ca}^{2+}$ release induced by EGF. ATP and UTP preferentially enhanced later cellular events, including migration. Cellular migration was enhanced further when cells were co-stimulated with EGF. In addition, the ATP mediated migration was reduced by the tri-peptide, RGD. The results indicate that immediate and long-term components of the wound response are mediated by tri-nucleotide receptors.

\section{Materials and methods}

\section{Reagents}

The nucleotides [adenosine $5^{\prime}$-triphosphate (ATP), uridine $5^{\prime}$-triphosphate (UTP), adenosine $5^{\prime}$-diphosphate (ADP), uridine $5^{\prime}$-diphosphate (UDP), $\beta, \gamma$-methyleneadenosine $5^{\prime}$ triphosphate $(\beta, \gamma-\mathrm{MeATP})$, and $2^{\prime}-3^{\prime}-O-(4-B e n z o y l b e n z o-$ yl)adenosine $5^{\prime}$-triphosphate (BzATP)], adenosine, apyrase, and Reactive Blue 2 were purchased from Sigma Chemical Company (St. Louis, MO). Human recombinant epidermal growth factor (EGF) and penicillin-streptomycin were purchased from Invitrogen Corporation (Carlsbad, $\mathrm{CA})$. The fluorescent $\mathrm{Ca}^{2+}$ indicator dye Fluo-3AM and pluronic acid were from Molecular Probes, Inc. (Eugene, OR). 1,2-bis(o-aminophenoxy)ethane- $N, N, N^{\prime}, N^{\prime}$-tetraacetic (BAPTA) was purchased from Calbiochem (La Jolla, CA). RGD and RGE peptides were purchased from American Peptide (Sunnyvale, CA).

\section{Cell culture}

Primary rabbit corneal epithelial cells and an established human corneal cell line were used. Human epithelial cells transformed (HCE-Ts) were established by Araki-Sasaki et al. [22], using an SV-40 recombinant adenovirus vector. Primary corneal epithelial cells were isolated and cultured from freshly extracted whole rabbits eyes (Pel-Freeze Biologicals (Rogers, AR) [7].

\section{$\mathrm{Ca}^{2+}$ imaging}

HCE-T cells and primary cells were grown to confluency on $22 \mathrm{~mm}^{2}$ coverslips and quiesced 18 to $24 \mathrm{~h}$ before experiments in unsupplemented serum-free keratinocyte medium (K-SFM). Cells were washed in a HEPESbuffered saline solution containing $137 \mathrm{mM} \mathrm{NaCl}, 5 \mathrm{mM}$ $\mathrm{KCl}, 4 \mathrm{mM} \mathrm{MgCl} 2,3 \mathrm{mM} \mathrm{CaCl} 2 \cdot 2 \mathrm{H}_{2} \mathrm{O}, 25 \mathrm{mM}$ glucose and $10 \mathrm{mM}$ HEPES [23]. Cells were incubated 20-30 min in $5 \mu \mathrm{M}$ Fluo-3AM resuspended in HEPES buffer supplemented with $0.02 \%$ pluronic acid in DMSO $[5,7,13]$. Coverslips were mounted in a flow through perfusion 
apparatus connected to inlet tubes with varying solutions and an outlet pump (Warner Instruments). The mounted coverslip was placed on the stage of a Zeiss Axiovert LSM 510 laser scanning confocal microscope, and cells were scanned with an Argon laser every 786 ms [7]. Cells were perfused with HEPES buffered saline at a rate that did not elicit a response, and baseline fluorescence was obtained. Cells were stimulated either by perfusing nucleotides or EGF prepared in HEPES buffered saline and/or by manually perturbing cells [5].

\section{$\mathrm{Ca}^{2+}$ data analysis}

$\mathrm{Ca}^{2+}$ data was recorded by LSM software as average fluorescence intensity $(F)$ for a region of interest over time. The region was either a $460 \mu \mathrm{m} \times 460 \mu \mathrm{m}$ field or single cells, over time. Raw data was entered into KaleidaGraph. Percent change in average fluorescence was calculated using the following formula

Percent change in average fluorescence $=\frac{\left(F-F_{0}\right)}{F_{0}} \times 100$

where $F_{0}$ is initial average fluorescence for the region of interest $[5,7]$. Data was either graphed as average maximal fluorescence of at least three different experiments or as percent change in average fluorescence for time course. For the injury experiments, the area cleared by the wound was excluded from calculations.

\section{Migration assay}

HCE-T cells were quiesced 18 to $24 \mathrm{~h}$ in unsupplemented K-SFM. Cells were washed in phosphate buffered saline (PBS), trypsinized, and the reaction was stopped with filtered soybean trypsin inhibitor as described previously [7]. Cells were resuspended at a concentration of 125,000 cells/100 $\mu \mathrm{l}$ in binding buffer (unsupplemented K-SFM, $0.05 \%$ gelatin and $25 \mathrm{mM}$ HEPES). Binding buffer, $600 \mu \mathrm{l}$, with or without added stimuli was placed in the wells of a 24 well plate. Costar Transwell inserts $(6.5-\mathrm{mm}$ diameter polycarbonate membranes, $8 \mu \mathrm{m}$ pore size) were placed into the wells, and $100 \mu \mathrm{l}$ of the cell suspension was added to the inserts. Experiments were conducted for $8 \mathrm{~h}$ at $37{ }^{\circ} \mathrm{C}$.

To collect conditioned wound medium, cells were washed and incubated in binding buffer. Cells were scrape wounded as described previously [13]. The wound medium was collected immediately and used in migration assays. Unwounded medium was defined as binding buffer added to cells and collected without injury to cells. The conditioned wound medium was also treated with apyrase prior to the migration assays.

To determine migration, upper and lower chambers were aspirated and rinsed with PBS. Cells were fixed at room temperature for $10 \mathrm{~min}$, rinsed with $\mathrm{PBS}$, and non-migrated cells were removed. Migrated cells were stained with propidium iodide $(5 \mu \mathrm{g} / \mathrm{ml})$ (Molecular Probes, Inc., Eugene, OR) for $5 \mathrm{~min}$ and rinsed with PBS. Membranes were mounted onto a slide with SlowFade Antifade
(Molecular Probes, Inc., Eugene, OR). For each membrane $\left(33.2 \mathrm{~mm}^{2}\right)$, six random $10 \times$ fields (one field $=1.37 \mathrm{~mm} \times$ $1.08 \mathrm{~mm}$, or $1.48 \mathrm{~mm}^{2}$ ) were photographed. Cells were counted and averaged for each membrane and experiments were performed in triplicate.

\section{Statistical analysis}

Values were given as the mean \pm SD. Statistical comparisons were made using Student's $t$-test with a stringency of $P<0.01$ for significance. Data were fit using KaleidaGraph to calculate concentration for half the maximal response $\left(\mathrm{EC}_{50}\right)$ and maximal possible change in fluorescence for a given agonist $\left(\Delta F_{\max }\right)$. A generalized single-site binding model was used as follows: $\Delta F=\frac{\Delta F_{\max } \times[L]}{E C_{50}+[L]}$, where $\Delta F$ is the percent change in fluorescence and $[L]$ is the concentration of the agonist.

\section{Results}

\section{Nucleotide dose response curves}

$\mathrm{Ca}^{2+}$ dose response curves were determined for ATP, UTP, ADP, UDP, and BzATP over a concentration range of $10^{-7}$ to $10^{-3} \mathrm{M}$ (Figure 1). The response to ATP and UTP was greater than that of ADP and UDP over the entire range. The BzATP response was similar to ADP and UDP at concentrations $\leq 10^{-4}$ but lower at higher concentrations. In addition, adenosine, an agonist for $\mathrm{P} 1$ receptors, and $\beta$, $\gamma$-MeATP, an agonist for P2X receptors, were evaluated. Neither of these agonists induced a change in intracellular $\mathrm{Ca}^{2+}$ (data not shown). The $\mathrm{EC}_{50}$ for ATP and UTP were found to be $(3.4 \pm 1.8) \times 10^{-6} \mathrm{M}$ and $(3.4 \pm 2.0) \times 10^{-6} \mathrm{M}$ respectively. The $\mathrm{EC}_{50}$ for $\mathrm{ADP}$ and UDP were higher than the tri-nucleotides, $(1.8 \pm 0.9) \times 10^{-4} \mathrm{M}$ and $(1.83 \pm 0.12)$ $\times 10^{-4} \mathrm{M}$. respectively. The $\mathrm{EC}_{50}$ for BzATP was $(8.6 \pm$ $5.9) \times 10^{-5} . R$ values for line fit were 0.96 for ATP, UTP, and UDP, 0.93 for ADP, and 0.91 for BzATP.

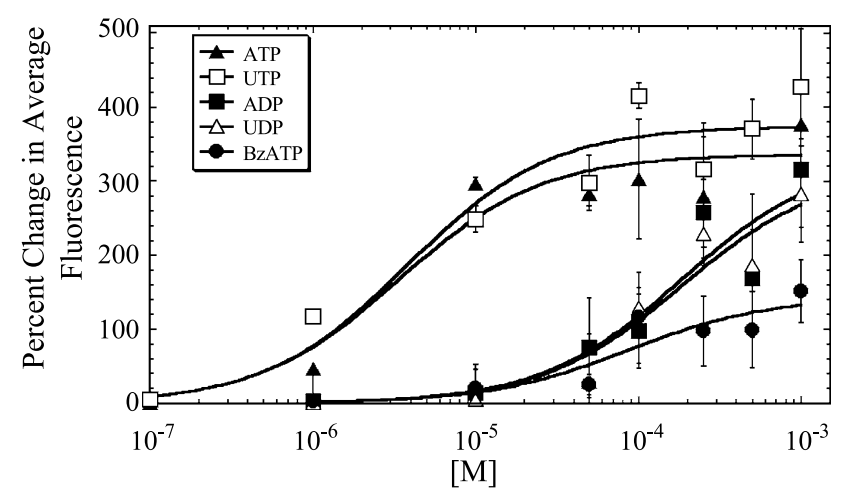

Figure 1. Nucleotide induced $\mathrm{Ca}^{2+}$ dose response curves. HCE-T cells were incubated in $5 \mu \mathrm{M}$ Fluo-3AM for $30 \mathrm{~min}$ and imaged every $786 \mathrm{~ms}$ using a flow through apparatus on an LSM 510 confocal. Cells were stimulated with the indicated concentration of nucleotide for $60 \mathrm{~s}$. Maximal percent change in average fluorescence of a $460 \mu \mathrm{m} \times 460 \mu \mathrm{m}$ field was determined. Data was fit to a generalized single-site binding model. Graph represents a minimum of three experiments at each concentration tested. 
To verify that $\mathrm{P} 2$ receptors caused the intracellular $\mathrm{Ca}^{2+}$ increase, cells were pre-incubated for $30 \mathrm{~min}$ in $100 \mu \mathrm{M}$ Reactive Blue 2 prior to experimentation. Cells were placed in a flow through system and washed for at least $50 \mathrm{~s}$ in HEPES buffered saline. Cells were stimulated with 100 $\mu \mathrm{M}$ of the indicated nucleotide for $100 \mathrm{~s}$ and washed again with HEPES buffer. Non-pretreated cells were used as control. Reactive Blue 2 lowered the $\mathrm{Ca}^{2+}$ response to nucleotides. The ATP and UTP responses were reduced by one-fifth, and the ADP and UDP responses were reduced by half.

\section{Role of nucleotides in injury response}

We have demonstrated that epithelial cells respond to nucleotides in a saturable manner. However, these results did not identify which $\mathrm{P} 2$ receptors were involved in the injury response. To evaluate the wound response, cells

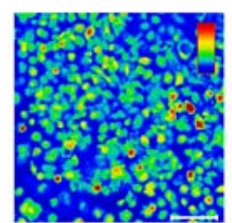

103 s

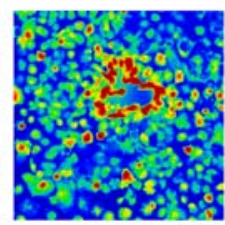

108

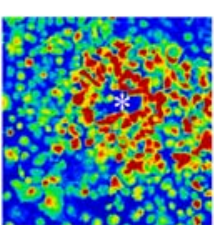

113

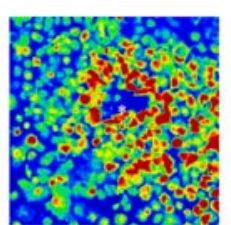

118

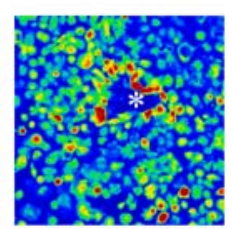

138 b

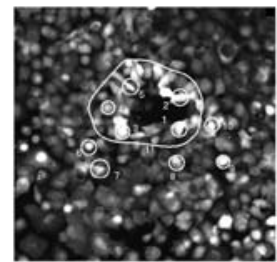

c

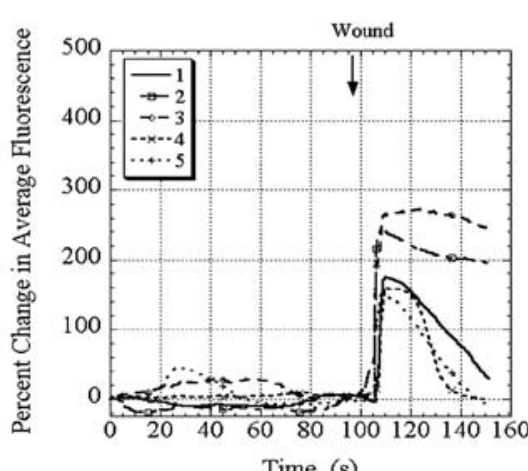

Time (s) d

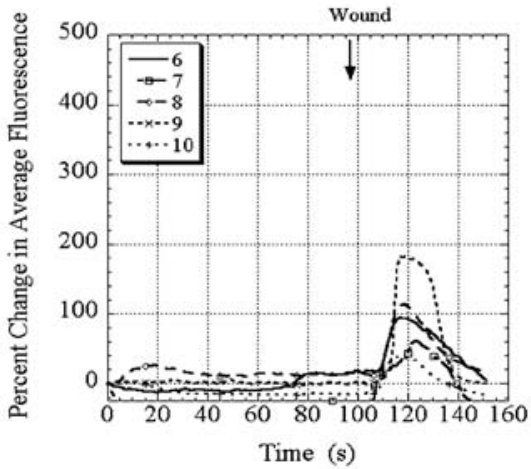

e

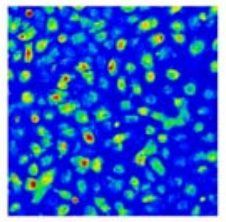

Os

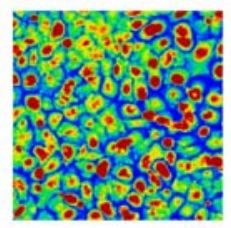

80

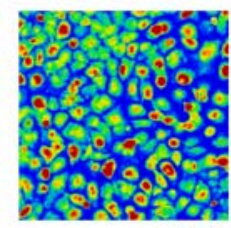

130

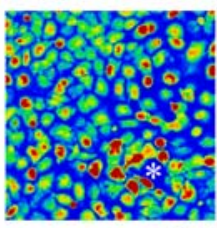

157

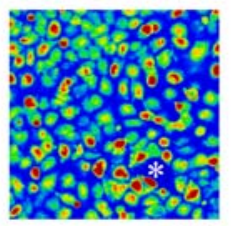

195 f

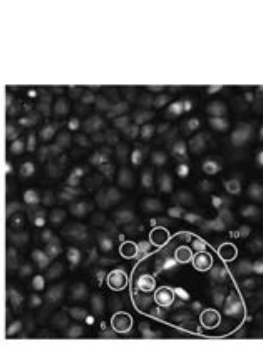

$\mathrm{g}$

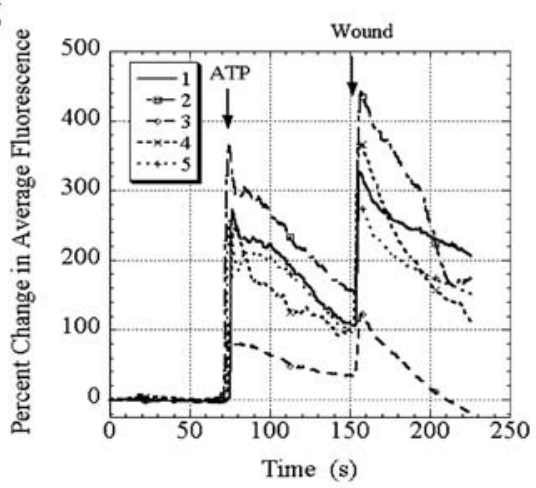

$\mathrm{h}$

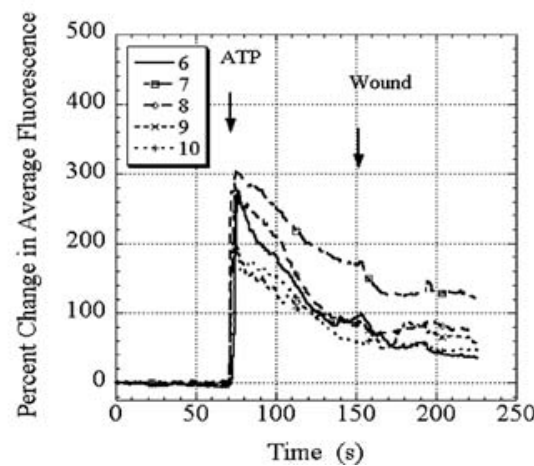

Figure 2. Pre-stimulation with ATP inhibits injury induced $\mathrm{Ca}^{2+}$ wave. Primary corneal epithelial cells were incubated in $5 \mu \mathrm{M}$ Fluo-3AM for 30 min and imaged in a flow through apparatus on an LSM 510 confocal. Cells were washed in HEPES buffered saline with Ca ${ }^{2+}$ for at least $30 \mathrm{~s}$, and stimulated by wounding or with ATP. Individual cells were analyzed for percent change in average fluorescence. Intensity scale is shown in (a) with red indicating highest $\mathrm{Ca}^{2+}$ levels and blue indicating lowest $\mathrm{Ca}^{2+}$ levels. The horizontal white bar in (a) represents $100 \mu \mathrm{m}$. a) Cells were washed in HEPES buffer containing $\mathrm{Ca}^{2+}$ and wounded. A series of images taken from a time course of a representative experiment of a wound (shown at asterisk) is presented. b) A single image taken after wounding is shown. Cells (\#1-5) immediately adjacent to the wound (c) and cells away (\#6-10) from the wound (d) were analyzed. e) Cells were washed in HEPES buffer containing $\mathrm{Ca}^{2+}$, stimulated with $100 \mu \mathrm{M}$ ATP ( 80 s), and wounded (157 s). A series of images taken from a time course of a representative experiment is presented (wound shown at asterisk). f) A single image taken after wounding is shown. Cells (\#1-5) immediately adjacent to the wound $(\mathrm{g})$ and cells away (\#6-10) from the wound (h) were analyzed. Images are representative of at least 10 independent experiments. 
were placed in a flow through apparatus. Background images were collected in HEPES buffered saline, and the cells perturbed manually (Figure 2a). Percent change in average fluorescence of individual cells adjacent to the wound (Figures 2b, c (\#1-5)) are shown inside the large white circle and graphed (Figure 2c). These depict a rapid increase in fluorescence after injury that is followed by attenuation. The rate of attenuation of injured cells was variable. While these cells did respond they were not a part of the calcium wave that propagated from the site of injury [5]. We also examined cells not immediately adjacent to the wound, cells involved in the wave (Figures $2 \mathrm{~b}, \mathrm{~d}$ ). When individual cells that were not adjacent to the wound were evaluated [(Figures 2b, d (\#6-10) (outside of white circle)], the percent response was lower on average and the response time was delayed (Figure 2d). The delay in response time could be accounted for by the time it took the $\mathrm{Ca}^{2+}$ wave to travel the distance to nonadjacent cells.

To evaluate what role ATP played in the initial injury response, cells were stimulated by ATP and wounded. To perform the experiment, cells were placed in the flow through apparatus, equilibrated with HEPES buffered saline, and stimulated with HEPES buffered saline con- taining $100 \mu \mathrm{M}$ ATP. The response to ATP was allowed to attenuate (approx. $80 \mathrm{~s}$ ), and then the cells were wounded (Figure 2e). The cells were analyzed for average change in percent fluorescence for individual cells adjacent to the wound (Figures 2f, g) and those involved in wave propagation (Figures $2 \mathrm{f}, \mathrm{h}$ ). As predicted from Figure $2 \mathrm{a}$ and $\mathrm{d}$, cells adjacent to the wound responded (Figures $2 \mathrm{f}, \mathrm{g}$ ). The $\mathrm{Ca}^{2+}$ wave was absent when it followed pretreatment with ATP (Figures 2f, h). In its place was a minor inflection at the time of injury that resembled the wound response induced in the absence of intracellular $\mathrm{Ca}^{2+}$ [5] (see Figure 5). These responses indicate that the injury response was inhibited by the desensitization of specific P2Rs by ATP.

To determine which nucleotides could desensitize the $\mathrm{Ca}^{2+}$ release in response to wounding, cells were pretreated with nucleotides and injured (Figures 3 and 4). Both ATP and UTP pre-stimulation inhibited the wound-induced wave (Figure 3), while ADP, UDP, and BzATP did not inhibit the injury induced $\mathrm{Ca}^{2+}$ wave (Figure 4). Together, these results indicate that both ATP and UTP desensitize receptors and inhibit the injury response at an equivalent molar concentration.

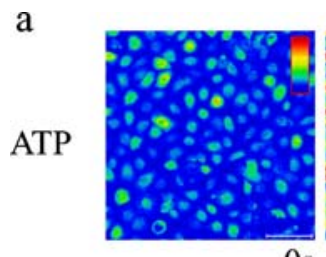

b

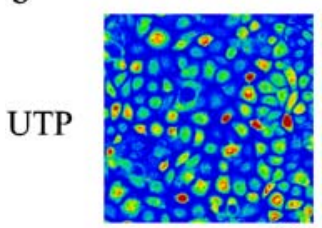

Os

$\mathrm{c}$

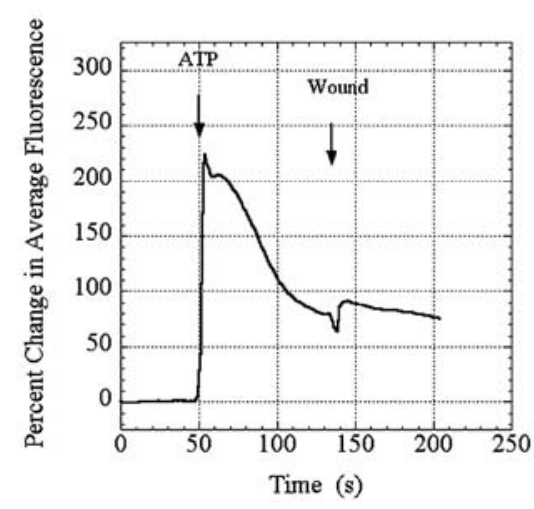

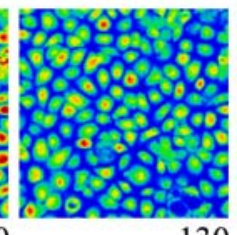

60
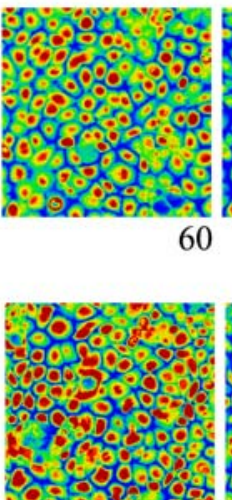

65

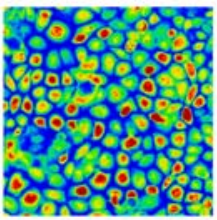

130

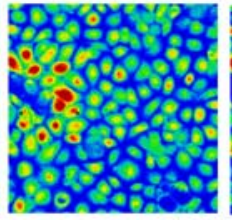

143

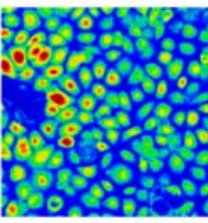

165

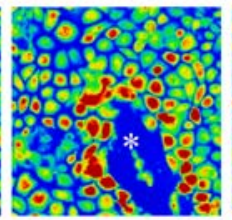

170

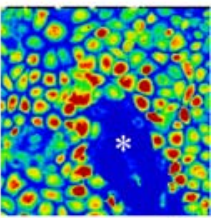

210

d

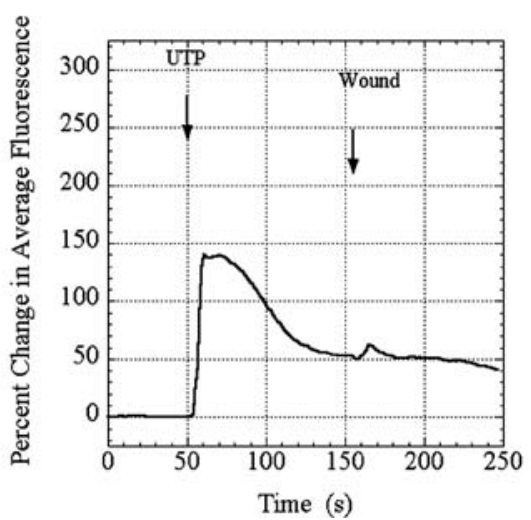

Figure 3. Tri-nucleotides attenuate the injury induced $\mathrm{Ca}^{2+}$ wave. Primary corneal epithelial cells were incubated in $5 \mu \mathrm{M}$ Fluo-3AM for 30 min and imaged in a flow through apparatus on an LSM 510 confocal. Cells were washed in HEPES buffered saline with Ca ${ }^{2+}$ for at least $30 \mathrm{~s}$ and stimulated with the indicated nucleotide and wounded. Intensity scale is shown in (a) with red indicating highest $\mathrm{Ca}^{2+}$ levels and blue indicating lowest Ca ${ }^{2+}$ levels. The horizontal white bar in (a) represents $100 \mu \mathrm{m}$. a, b) Cells were washed in HEPES buffer with $\mathrm{Ca}^{2+}$, stimulated with $100 \mu \mathrm{M}$ of the indicated nucleotide, and wounded. A series of images taken from a time course of a representative experiment is presented (wound shown at asterisk). c, d) Percent change in average fluorescence for the whole field $(460 \mu \mathrm{m} \times 460 \mu \mathrm{m})$ was calculated and graphed over the time course for each experiment. Images are representative of at least 10 independent experiments. Series of images are taken from Movie 1 (see online version of article at www.springeronline.com). 
a

ADP
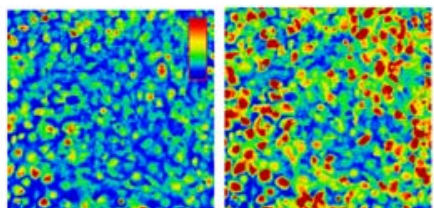

0 s

85
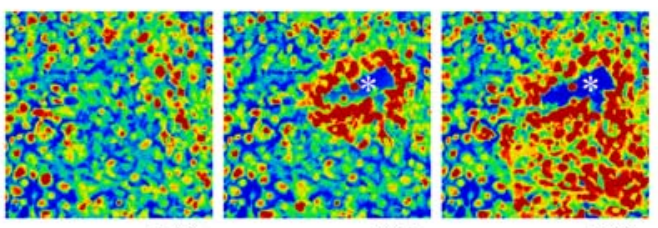

b
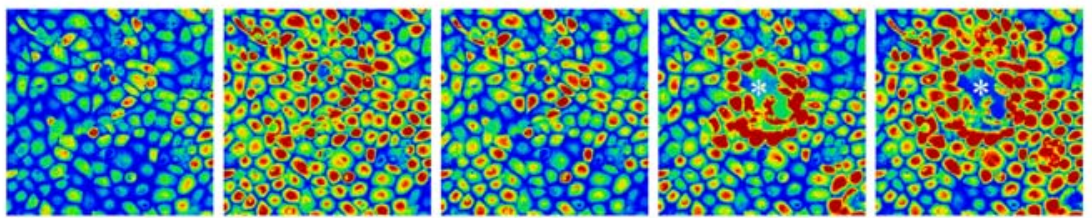

Os

75

140

152

158

c
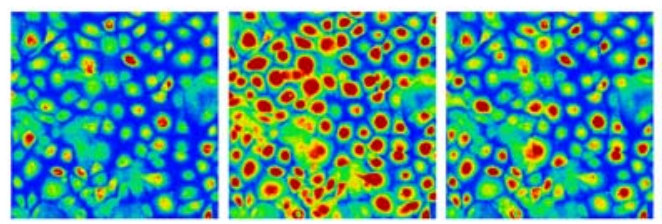

0 s

75

d

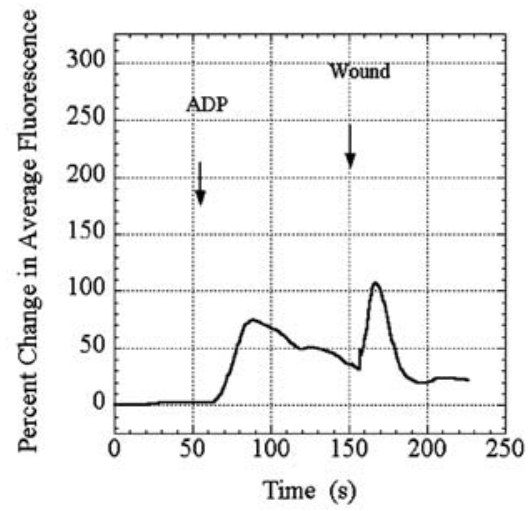

140

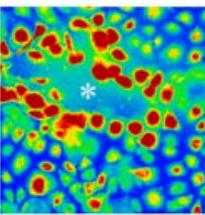

164

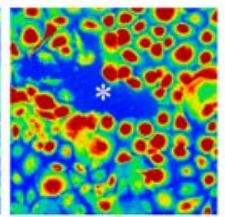

172

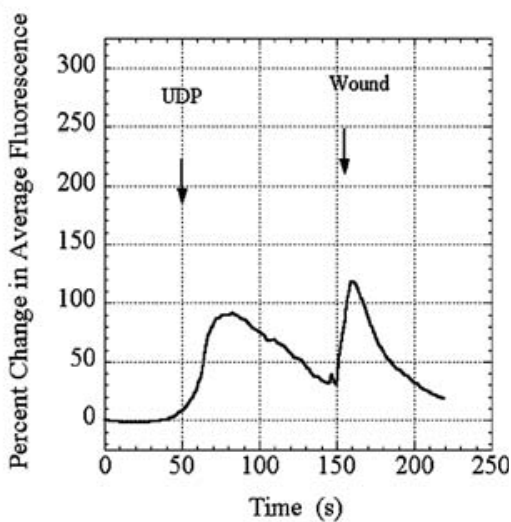

f

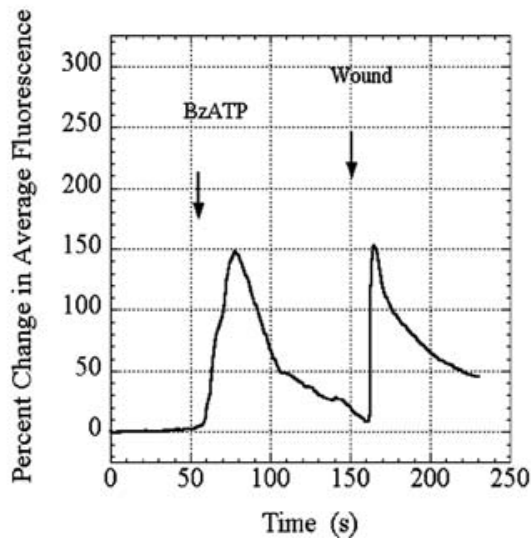

Figure 4. Di-nucleotides and BzATP do not attenuate the injury induced $\mathrm{Ca}^{2+}$ wave. Primary corneal epithelial cells were incubated in $5 \mu \mathrm{M}$ Fluo$3 \mathrm{AM}$ for $30 \mathrm{~min}$ and imaged in a flow through apparatus on an LSM 510 confocal. Cells were washed in HEPES buffered saline with $\mathrm{Ca}^{2+}$ for at least 30 $\mathrm{s}$ and stimulated with the indicated nucleotide and wounded. Intensity scale is shown in (a) with red indicating highest $\mathrm{Ca}^{2+}$ levels and blue indicating lowest $\mathrm{Ca}^{2+}$ levels. The horizontal white bar in (a) represents $100 \mu \mathrm{m}$. (a-c) Cells were washed in HEPES buffer with $\mathrm{Ca}^{2+}$, stimulated with $100 \mu \mathrm{M}$ of the indicated nucleotide, and wounded. A series of images taken from a time course of a representative experiment is presented (wound shown at asterisk). (d-f) Percent change in average fluorescence for the whole field $(460 \mu \mathrm{m} \times 460 \mu \mathrm{m})$ was calculated and graphed over the time course for each experiment. Images are representative of at least 10 independent experiments. Series of images are taken from Movie 1 (see online version of article at www.springeronline.com). 
To evaluate the inflection detected in Figures $2 \mathrm{e}-\mathrm{h}$, cells were pretreated with BAPTA $(100 \mu \mathrm{M})$ for $30 \mathrm{~min}$ and individual cells were analyzed (Figures 5a-d). Cells responded to the injury in a manner similar to the cultures that had been pretreated with ATP (Figures 3 and 4). These results indicate that the cellular response adjacent to the wound did not occur via $\mathrm{P} 2 \mathrm{Y}$ receptor signaling since the $\mathrm{Ca}^{2+}$ increase came from extracellular stores a

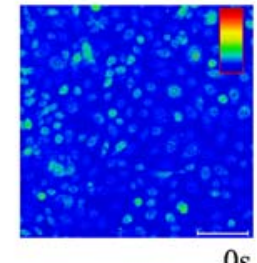

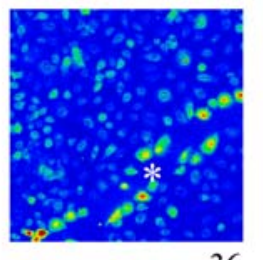

36

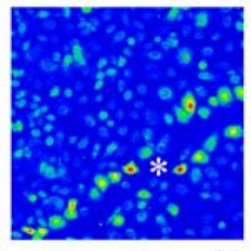

45

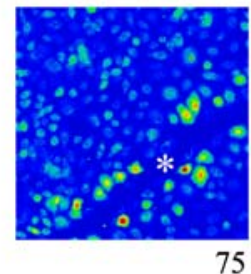

75 b

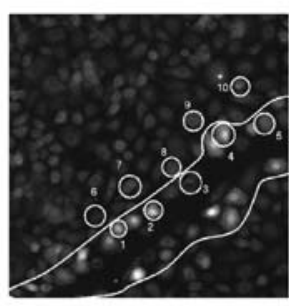

C

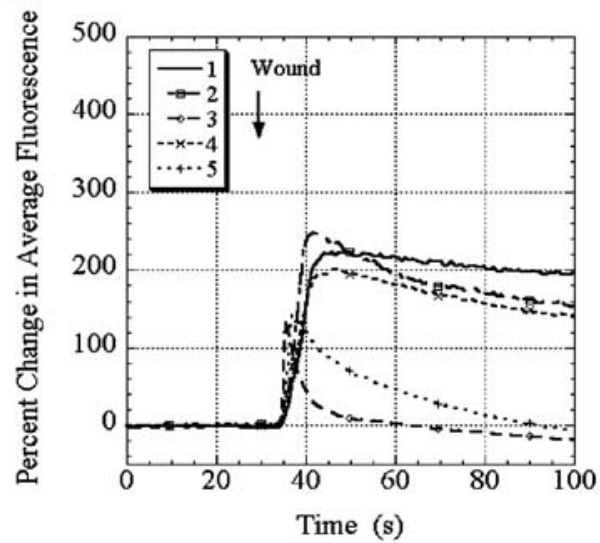

d

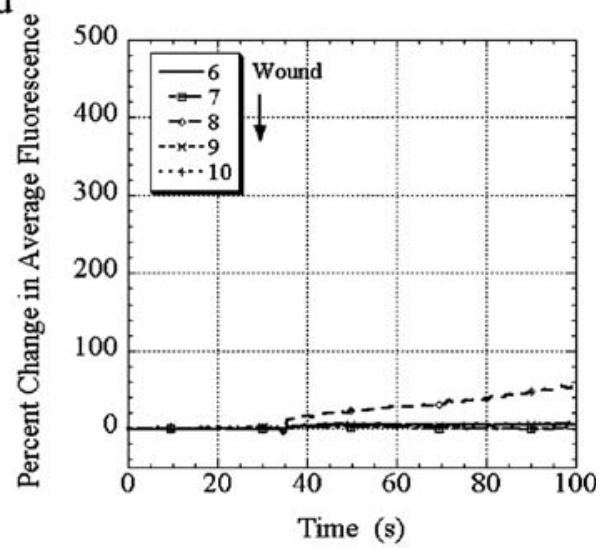

e

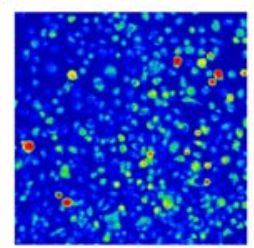

$0 \mathrm{~s}$

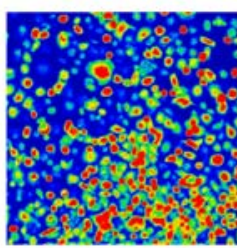

106

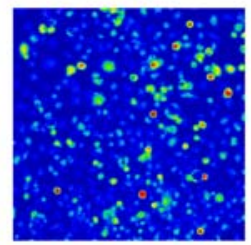

182

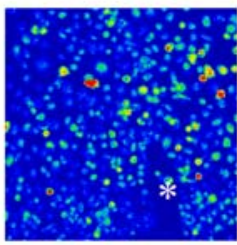

196

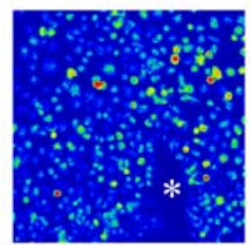

211 f

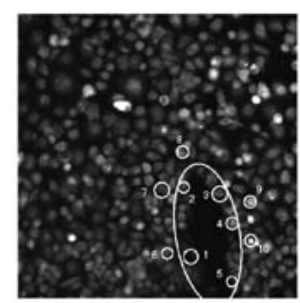

g

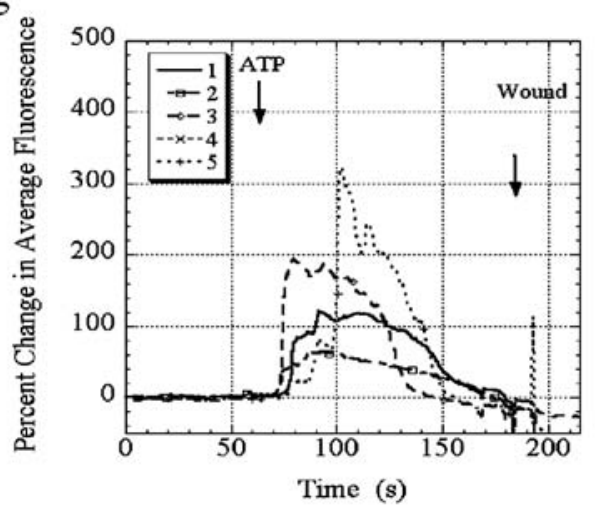

h

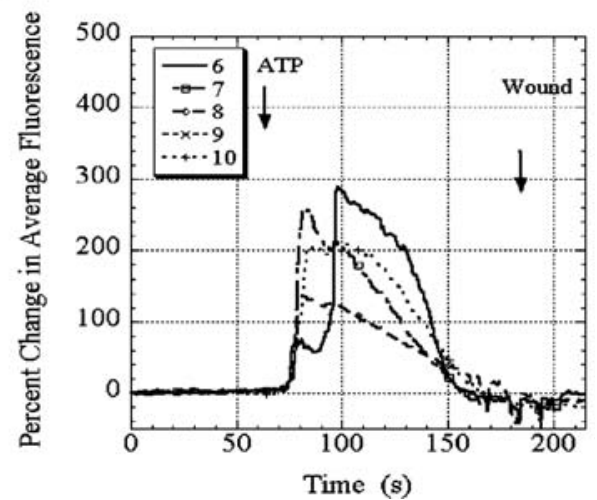

Figure 5. $\mathrm{Ca}^{2+}$ free media inhibits an injury response after ATP stimulation. Primary corneal epithelial cells were incubated in $5 \mu \mathrm{M}$ Fluo-3AM for 30 min and imaged in a flow through apparatus on an LSM 510 confocal. Cells were washed in HEPES buffered saline for at least 30 s, and stimulated by wounding or ATP. Individual cells were analyzed for percent change in average fluorescence. Intensity scale is shown in (a) with red indicating highest $\mathrm{Ca}^{2+}$ levels and blue indicating lowest $\mathrm{Ca}^{2+}$ levels. The horizontal white bar in (a) represents $100 \mu \mathrm{m}$. a) Cells were pre incubated in BAPTA (100 $\left.\mu \mathrm{M}\right)$ washed in HEPES buffer containing $\mathrm{Ca}^{2+}$ and wounded. A series of images taken from a time course of a wound (shown at asterisk) of a representative experiment is presented. b) A single image taken after wounding is shown. Cells (\#1-5) immediately adjacent to the wound (c) and cells away (\#6-10) from the wound (d) were analyzed. e) Cells were washed in $\mathrm{Ca}^{2+}$ free HEPES buffer containing EGTA, stimulated with $100 \mu \mathrm{M}$ ATP, and wounded. A series of images taken from a representative time course is presented (wound shown at asterisk). f) A single image taken after wounding is shown. Cells (\#1-5) immediately adjacent to the wound (g) and cells away (\#6-10) from the wound (h) were analyzed. Images are representative of at least 10 independent experiments. The series of images are taken from Movie 2 (see online version of article at www.springeronline.com). 
(Figures $5 \mathrm{a}-\mathrm{d}$ ). This agrees with previous results using thapsigargin [5]. To evaluate the requirement for extracellular $\mathrm{Ca}^{2+}$, cultures were placed in the flow through apparatus in $\mathrm{Ca}^{2+}$ free HEPES buffer containing EGTA. These cells were stimulated with $100 \mu \mathrm{M}$ ATP made in $\mathrm{Ca}^{2+}$ free HEPES buffered saline. Once the response had attenuated (approx. $100 \mathrm{~s}$ ), the cells were wounded (Figure 5e), and individual cells were analyzed for average change in percent fluorescence in cells adjacent to the wound margin (Figures 5f, g) and those involved in wave propagation (Figures 5f, h; as in Figure 2). When the experiment was performed in $\mathrm{Ca}^{2+}$ free media, the inflection detected previously in the injury response was absent, completely eliminating any $\mathrm{Ca}^{2+}$ response to injury (Figures $5 \mathrm{e}-\mathrm{h}$ ).

\section{Nucleotides affect EGF induced $\mathrm{Ca}^{2+}$ response}

Cross-talk between the EGF and ATP signaling pathways occurs in many cell systems. To determine if this was a property unique to ATP, the response to EGF was evaluated after pre-stimulation with other nucleotides. HCE-Ts were perfused with HEPES buffered saline to establish baseline fluorescence, and the cells were stimulated with $100 \mu \mathrm{M}$ ATP, UTP, ADP, UDP or BzATP for $100 \mathrm{~s}$. Cells were washed with HEPES for $100 \mathrm{~s}$ and stimulated with $8 \mathrm{nM}$ EGF for $100 \mathrm{~s}$. Maximal percent change in fluorescence of the entire $460 \mu \mathrm{m} \times 460 \mu \mathrm{m}$ field was calculated (Figure 6a). The results were compared with cells washed with HEPES buffer and stimulated with $8 \mathrm{~nm}$ EGF alone for $100 \mathrm{~s}$ (- pretreatment). Cells exhibited an attenuated $\mathrm{Ca}^{2+}$ response upon EGF stimulation when they were pretreated with either ATP or UTP. In contrast, when the cells were pre-stimulated with BzATP, ADP, or UDP, there was no detectable desensitization (Figure 6a). The reverse experiment was performed where cells were pre-stimulated with EGF and then by specific nucleotides (data not shown). Pretreatment with EGF did not desensitize the cells indicating that EGFR stimulation with EGF did not inhibit the response to nucleotides.

As desensitization occurred after cells were pre-stimulated with ATP or UTP and wounded or stimulated with EGF, our goal was to determine if desensitization of the EGF receptor occurred in our wound model. Cells were placed in the flow through apparatus, perfused with HEPES buffered saline to establish baseline fluorescence, and injured. Once fluorescence returned to the base line, the cells were stimulated with EGF. The analysis was performed on individual cells that responded to both the injury and EGF (Figure 6b). Results were compared to individual cells stimulated with EGF alone. The $\mathrm{Ca}^{2+}$ response to EGF was significantly lowered after injury. The high standard deviation was due to the variable size of the wound.

\section{Nucleotides and EGF induce cell migration}

The long-term effects of $\mathrm{P} 2$ receptors on wound healing were examined using Transwell migration assays. Previ-

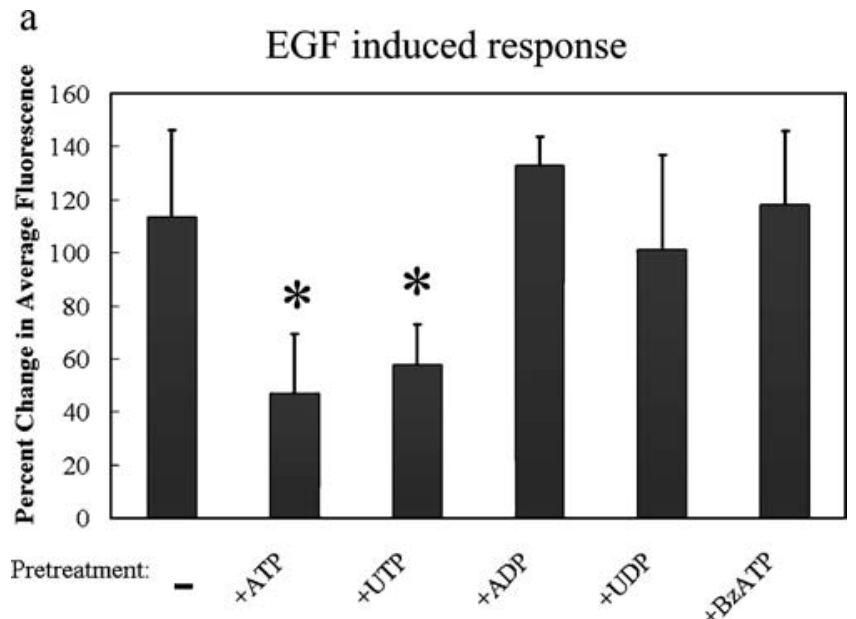

$\mathrm{b}$

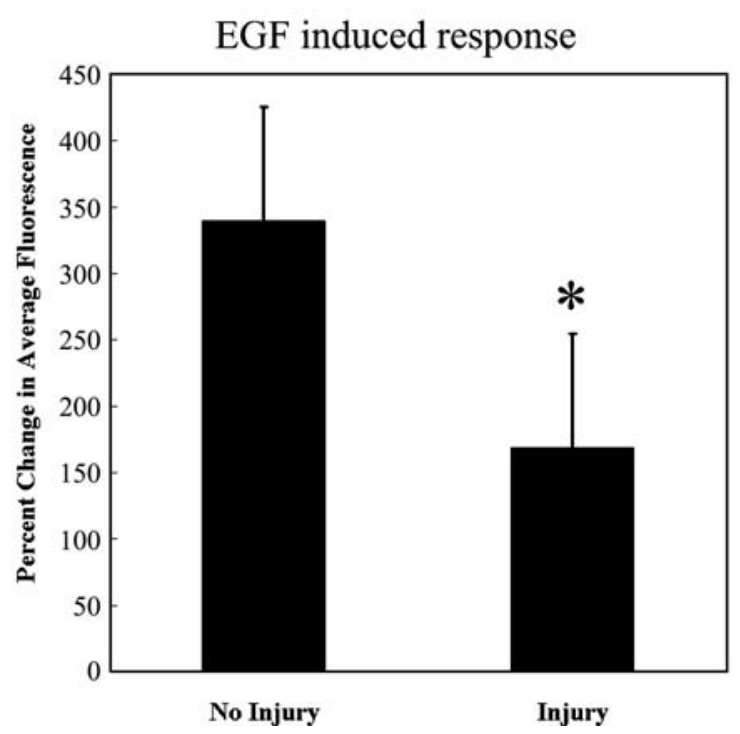

Figure 6. Injury and tri-nucleotides decrease subsequent EGF induced $\mathrm{Ca}^{2+}$ response. HCE-T cells were incubated in $5 \mu \mathrm{M}$ Fluo-3AM for $30 \mathrm{~min}$ and imaged every $786 \mathrm{~ms}$ in a flow through apparatus on an LSM 510 confocal. a) Cells were stimulated with $100 \mu \mathrm{M}$ of the indicated nucleotide for $100 \mathrm{~s}$, washed in HEPES buffered saline for $100 \mathrm{~s}$, and then stimulated with $8 \mathrm{nM}$ EGF or stimulated with EGF without pretreatment. Maximal percent change in average fluorescence of a 460 $\mu \mathrm{m} \times 460 \mu \mathrm{m}$ field was determined. b) Cells were either wounded and stimulated with $8 \mathrm{nM}$ EGF or stimulated with EGF without injury. Individual cells were selected for analysis. In the wound model, cells that responded to the wound were selected. $\left(t\right.$-test, $\left.{ }^{*} P<0.0005\right)$ Data represent a minimum of three independent experiments.

ously we showed that P2 receptors were necessary for wound repair in directed migration scratch assays [7]. Furthermore, we demonstrated that migration was optimal at $1 \mu \mathrm{M}$ for ATP and $0.16 \mathrm{nM}$ for EGF in Transwell assays [7]. In these experiments, migration to other nucleotides and adenosine were evaluated over a range of concentrations from 0.1 to $100 \mu \mathrm{M}$ (Figure 7). Optimal migration for ADP and BzATP occurred at $10 \mu \mathrm{M}$ (Figures 7a, b), while optimal migration for ATP and UTP occurred at 1 $\mu \mathrm{M}$ ([7] and data not shown). UDP and $\beta, \gamma$-MeATP did not induce migration at any concentration (Figures $7 \mathrm{c}, \mathrm{d}$ ). To assess preferential migration to any one particular nucle- 
a

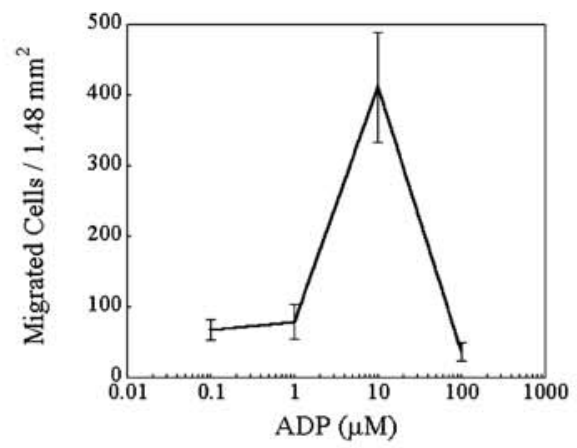

b

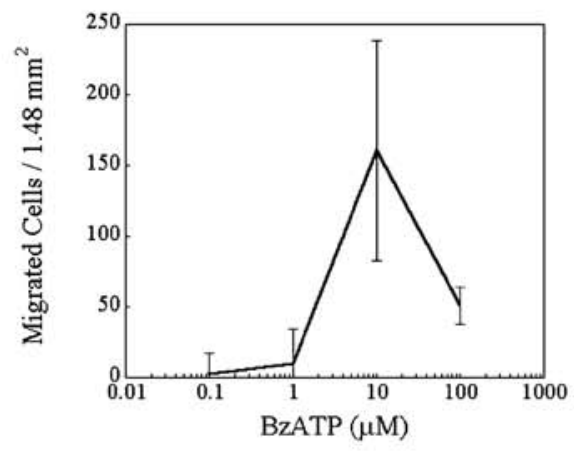

c

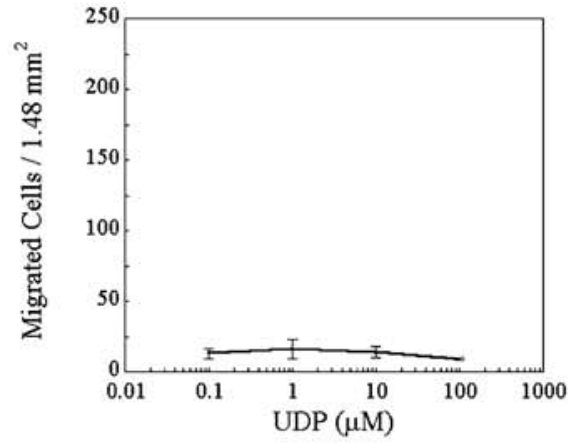

d

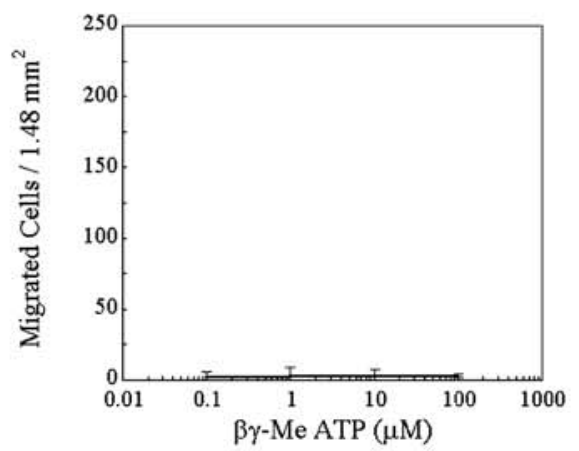

e

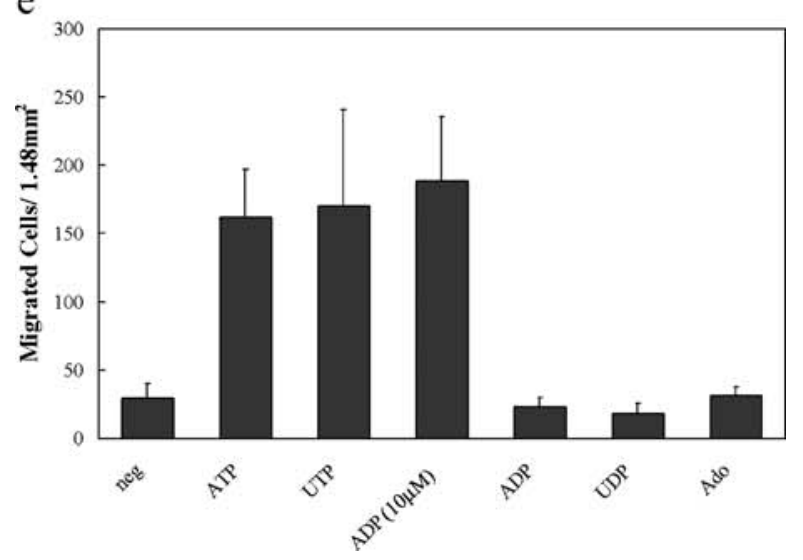

otide or adenosine, the nucleotides and adenosine were evaluated and compared. The cellular response was tested at $1 \mu \mathrm{M}$, the optimal concentration for ATP and UTP. In addition, ADP was tested at $10 \mu \mathrm{M}$, its optimal concentration. ATP, UTP, and ADP induced comparable migration at their optimal concentrations $(162 \pm 39,170 \pm 70$, and $188 \pm 47$ cells $/ 1.48 \mathrm{~mm}^{2}$, respectively). However, ADP at 1 $\mu \mathrm{M}$, UDP, adenosine, or binding buffer did not induce cell migration $(23 \pm 7,18 \pm 7,31 \pm 6$ and $29 \pm 11$ cells $/ 1.48$ $\mathrm{mm}^{2}$, respectively) (Figure 7e).

We evaluated the role of factors released into the wound media on cell motility and compared these effects to stimulation with nucleotides and EGF. Wound media was collected immediately after injury and added to migration assay chambers. Luciferase assays performed on wound media demonstrated presence of ATP [5]. Cell migration was 3.7-fold greater when cells were stimulated with wound media compared to wound media treated with apyrase or unwounded control media (Figure 8a). Previously we established that epithelial cells migrate to ATP or EGF in a dose dependent manner and optimal migration was determined to be $1 \mu \mathrm{M}$ and $0.16 \mathrm{nM}$ respectively [24]. To evaluate the combined effect of ATP and EGF, cells were co-stimulated with the optimal concentrations of each and compared. In a representative experiment an average of $369( \pm 34)$ cells migrated/1.48 $\mathrm{mm}^{2}$ in response to 0.16 nM EGF while an average of $314( \pm 31)$ cells migrated/1.48 $\mathrm{mm}^{2}$ in response to $1 \mu \mathrm{M}$ ATP (Figure 8b). When cells were co-stimulated with $1 \mu \mathrm{M}$ ATP and $0.16 \mathrm{nM}$ EGF, migration increased more than threefold with an average of $1043( \pm 66)$ cells $/ 1.48 \mathrm{~mm}^{2}$ (Figure $\left.8 \mathrm{~b}\right)$. Co-stimulation experiments were performed with UTP, ADP and UDP at their respective optimal concentrations (Figures 7 and 8c). Cells exposed to ADP or UDP $(1 \mu \mathrm{M})$ and co-stimulated with EGF $\left(527 \pm 61\right.$ and $637 \pm 51$ cells $/ 1.48 \mathrm{~mm}^{2}$, respectively) showed migration similar to that of EGF alone $\left(457 \pm 115\right.$ cells $\left./ 1.48 \mathrm{~mm}^{2}\right)$. When cells were costimulated with UTP and EGF, migration was enhanced in an additive manner $\left(801 \pm 133\right.$ cells $\left./ 1.48 \mathrm{~mm}^{2}\right)$. In addition when cells were exposed to $10 \mu \mathrm{M}$ ADP and EGF, migration was greater than either alone $(753 \pm 173$ cells/ $1.48 \mathrm{~mm}^{2}$ ).

To understand how nucleotides regulate cell migration, we asked whether integrins mediated the response. Integrins are known to play an important role in cell migration, and the integrin binding tri-peptide, RGD, that is found in the first extracellular loop of the $\mathrm{P}_{2} \mathrm{Y}_{2}$ receptor, has been shown to interact with integrins [20]. In addition, expression of $\alpha_{6} \beta_{4}$ in corneal epithelial cells is up-regulated by

Figure 7. Cell migration is nucleotide specific. Transwell migrations were performed for $8 \mathrm{~h}$ at $37{ }^{\circ} \mathrm{C}$ with the indicated nucleotide. HCE-T cells were stained with propidium iodide, counted in six randomly chosen fields $\left(1.46 \mathrm{~mm}^{2}\right)$, and averaged. Dose response curves for a) ADP, b) BzATP, c) UDP, and d) $\beta, \gamma$-MeATP are shown. Experiments were performed at least three times and representative curves were chosen. e) Cells were stimulated with binding buffer (neg), $1 \mu \mathrm{M}$ ATP, UTP, ADP, UDP, or Adenosine (Ado), or $10 \mu \mathrm{M}$ ADP. Experiments were performed in triplicate. 
EGFR activation [18]. To evaluate the role of integrin receptors in nucleotide mediated migration, RGD peptide was added to the cell suspension prior to its addition to the Transwell chamber. RGE peptide was used to control for non-specific binding. Cells were migrated to binding buffer

a

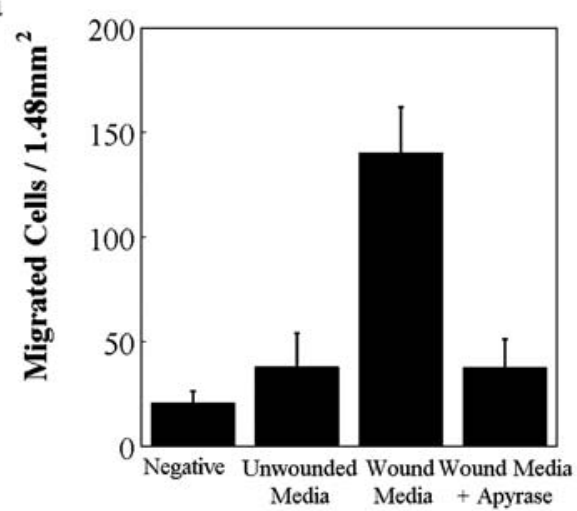

b

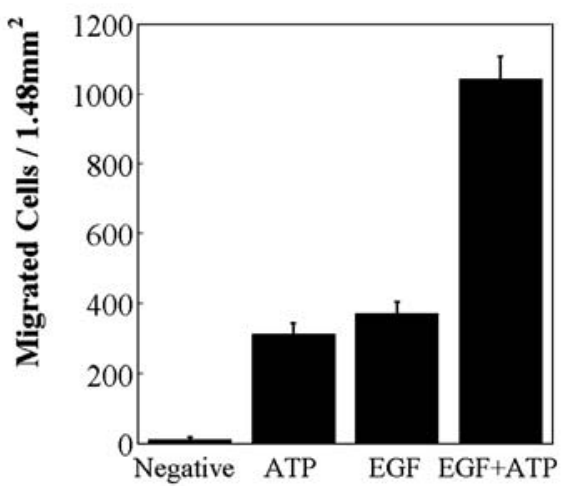

$\mathrm{C}$

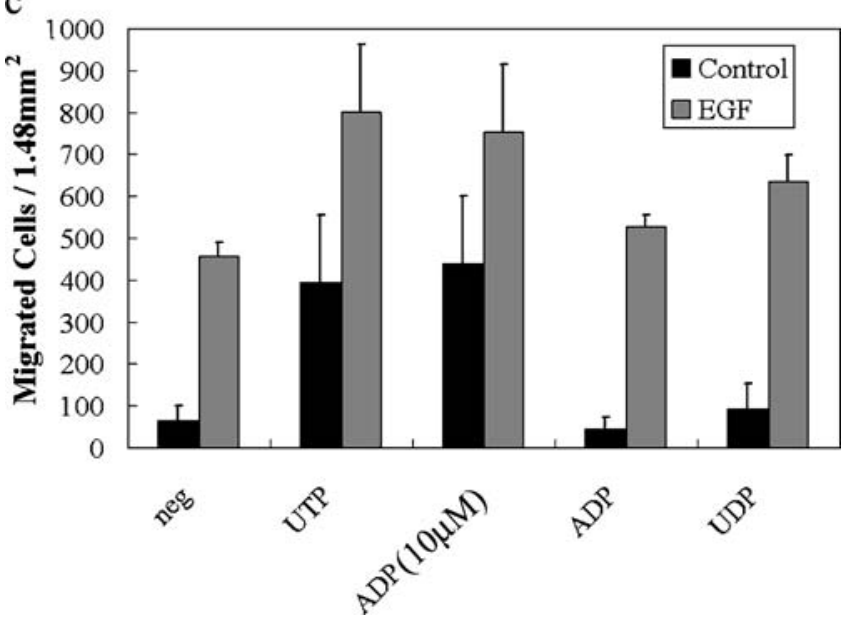

Figure 8. Wound media, nucleotides, and EGF mediate cell migration Transwell migrations were performed for $8 \mathrm{~h}$ at $37^{\circ} \mathrm{C}$ with the indicated nucleotides and/or EGF. HCE-T cells were stained with propidium iodide, counted in six randomly chosen fields $\left(1.46 \mathrm{~mm}^{2}\right)$ and averaged. a) Migration of cells stimulated with wound media were compared to those stimulated with unwounded control media, wound media treated with apyrase and binding buffer (negative). b) A representative experiment is shown where cells were stimulated with optimal concentration of ATP $(1 \mu \mathrm{M})$ and EGF $(0.16 \mathrm{nM})$ and compared to co-stimulation with ATP and EGF and negative binding buffer. c) Cells were simulated with binding buffer (neg), $1 \mu \mathrm{M}$ UTP, ADP, or UDP, or $10 \mu \mathrm{M}$ ADP +/- 0.16 nm EGF.

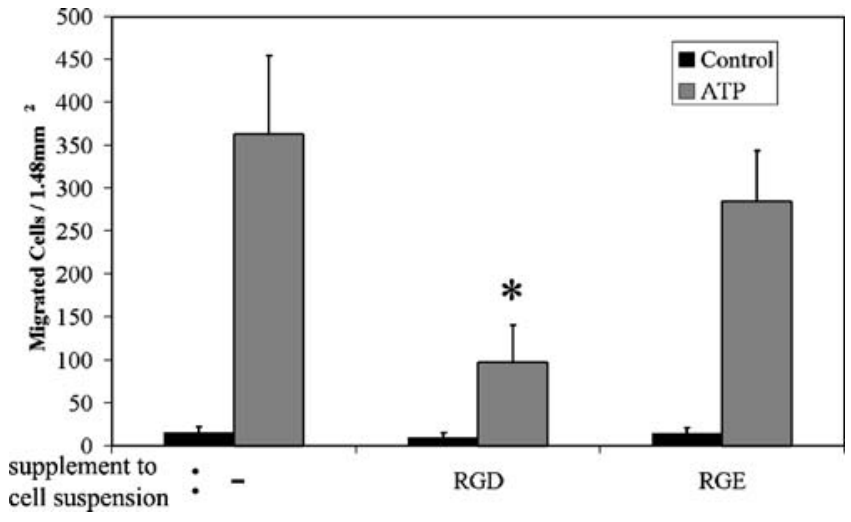

Figure 9. ATP and integrins mediate cell migration. Transwell migrations were performed for $8 \mathrm{~h}$ at $37{ }^{\circ} \mathrm{C}$ with the indicated nucleotides. HCE-T cells were stained with propidium iodide, counted in six randomly chosen fields $\left(1.46 \mathrm{~mm}^{2}\right)$ and averaged. RGD or RGE peptide, $1 \mu \mathrm{M}$, was added to the cell suspension. Cells were stimulated with binding buffer (control) or $1 \mu \mathrm{M}$ ATP. ( $t$-test, $* P<0.0005)$ Experiments were performed in triplicate.

or $1 \mu \mathrm{M}$ ATP. When either the RGD or RGE peptide was added to the cells migrating to binding buffer, there was no detectable difference over control (Figure 9). Cells stimulated with ATP migrated $362( \pm 92)$ per field. Interestingly, cell migration was reduced almost fourfold when RGD was present $\left(96 \pm 43\right.$ cells $\left./ 1.48 \mathrm{~mm}^{2}\right)$ (Figure 9). The control peptide did not decrease migration significantly from control (284 \pm 59$)$. Since RGD peptide can inhibit migration, it is likely integrins play a role in ATP induced cell migration. The nucleotide receptors, EGFR, and integrins mediate calcium signaling and cell migration. Thus, interaction between these protein families may be critical in regulating the cellular signals after injury.

\section{Discussion}

The results of these studies demonstrate that $\mathrm{P} 2$ receptors play a role in the initial cellular responses that occur after injury and the long-term signals that are necessary for wound closure in corneal epithelial cells. We have demonstrated that nucleotides are the active component released with injury and are responsible for the intercellular $\mathrm{Ca}^{2+}$ wave that is propagated in neighboring cells [5, 13]. We have shown that ATP, UTP, ADP, UDP and BzATP promote an intracellular $\mathrm{Ca}^{2+}$ increase, $\beta, \gamma \mathrm{Me}$-ATP does not. Our goal was to demonstrate that nucleotides play a prominent role in the cellular response to injury, in migration, and in the cross-talk with EGF.

Recently involvement of $\mathrm{P} 2$ receptors in wound healing has begun to be demonstrated [2]. Desensitization experiments demonstrate the role of nucleotides in the injury response. We have shown pretreatment of cells with ATP and UTP inhibits the response to a subsequent wound (Figure 3). Several explanations are plausible: 1) Specific receptors desensitize via receptor internalization or signal transduction down regulation [25] or 2) When cells are exposed to a solution of a tri-nucleotide, ATP and/or UTP 
receptors have bound agonist thus saturating the receptors. We predict that the amount of nucleotide used to desensitize the wound approximates the concentration needed for the maximal $\mathrm{Ca}^{2+}$ response (Figure 1). In either case, the result is that nucleotides that are released would not be able to induce any further effect upon the receptors. In addition, injury, ATP and UTP, induce a decrease in the EGF induced $\mathrm{Ca}^{2+}$ response (Figure 6). Since nucleotides are released with injury [13], we hypothesize that desensitization of the EGF receptor occurs via nucleotides. In contrast, while ADP and UDP cause homologous desensitization of their own $\mathrm{Ca}^{2+}$ signal [7], ADP, UDP, and BzATP do not affect either the EGF or wound response even when the receptors are saturated (Figures 4 and 6). Therefore, we hypothesize that $\mathrm{P}_{2} \mathrm{Y}_{1}, \mathrm{P}_{2} \mathrm{Y}_{6}$, and $\mathrm{P} 2 \mathrm{X}_{7}$ receptors do not play a role in the $\mathrm{Ca}^{2+}$ wave that occurs after injury.

We have demonstrated that the source of the calcium for the injury induced wave is intracellular ([5] and Figure 5). Pretreatment with either thapsigargin or BAPTA inhibits the $\mathrm{Ca}^{2+}$ wave but not oscillations of cells at the wound margin. In addition, pretreatment with either ATP or UTP inhibits only the wave but not the $\mathrm{Ca}^{2+}$ increase in the cells adjacent to the wound. Cells adjacent to the wound edge utilize extracellular calcium (Figure 5), but the method of extracellular calcium entry is unknown. One possibility is that the plasma membranes of the injured cells are damaged, and $\mathrm{Ca}^{2+}$ freely enters. The response could also be mediated via stress receptors or P2X receptors, both of which are ion channels that permit entry of extracellular calcium [26]. While these cells are not involved in the propagation of the wave, we cannot rule out the possibility that they play a role in wound healing, and that is an area of current exploration.

Activation of intracellular signaling pathways by $\mathrm{P} 2$ receptors is emerging as intricate patterns of cell specific processes. Involvement of $\alpha_{\mathrm{v}} \beta_{3}$ integrins has been shown to be essential for both ATP induced intracellular $\mathrm{Ca}^{2+}$ increase and ERK1/2 activation in $1321 \mathrm{~N} 1 \mathrm{P}_{2} \mathrm{Y}_{2}$ transfected cells [20]. We have shown in our system that integrins play a role in the response to nucleotides (Figure 9). As integrins are known to play a role in cell migration and wound healing, their coordinated role in nucleotide signaling is of great interest. Purinergic signaling is also known to activate downstream signaling events using a number of receptors. We have shown that ATP, UTP, ADP, and UDP promote activation of ERK1/2, but $\alpha, \beta$-MeATP and $\beta, \gamma-$ MeATP do not [13]. $\mathrm{P} 2 \mathrm{X}_{2}$ and $\mathrm{P} 2 \mathrm{Y}_{1}$ receptors have been shown to play a role in activating ERK1/2 in stretch induced injury of astrocytes in $\mathrm{Ca}^{2+}$ dependent manner [27]. In contrast in embryonic kidney cells, $\mathrm{P}_{2} \mathrm{X}_{7}$ activates ERK1/2 in a $\mathrm{Ca}^{2+}$ independent manner [28]. Additionally $\mathrm{PKC}$ and PKD both have been shown to play role in $\mathrm{P} 2 \mathrm{X}_{7}$ induced ERK1/2 activation [29]. In pro-monocytic cells, activation of ERK1/2 by $\mathrm{P}_{2} \mathrm{Y}_{2}$ has been shown to involve c-Src but not PKC [30].

Recently, the P2YRs have been hypothesized to play a role in cross-talk with the EGFR [7, 13, 21, 31, 32]. There are a number of potential pathways, several of which may occur. One current hypothesis is cross-talk occurs via the triple membrane pass system where GPCR activated matrix metalloproteases (MMPs) cleave pro-heparin binding (HB)EGF from the membrane and HB-EGF can then activate the EGFR $[33,34]$. Another potential method for cross-talk is via Src. While Src is known to play a role in the phosphorylation of EGFR, its involvement in corneal epithelial injury has not been determined. GPCR stimulation has been found to lead to phosphorylation of the EGFR in a Src and/or Pyk2 dependent manner in many cell types [21, 31, $35,36]$. Future experiments will be performed to test the hypothesis that Src and Pyk2 play an active role in nucleotide-mediated activation of the EGFR in corneal epithelial cells. Inhibition of the EGFR activation with tyrphostin has been shown to inhibit ATP induced cell migration in epithelial cells [7]. These indicate that cross talk between GPCR and the EGFR occur over the entire time course of wound response and repair.

ATP and UTP are the major players in $\mathrm{Ca}^{2+}$ waves after injury and the cross talk with the EGFR (Figures 3 and 6). However, this does not preclude that other nucleotides may mediate other facets of the wound response. While ADP and BzATP do not play a role in the injury induced $\mathrm{Ca}^{2+}$ wave, they can stimulate migration, albeit at a higher concentration than ATP or UTP (Figure 7). Though UDP does not stimulate migration, both ADP and UDP have the ability to activate downstream signals. We have shown that ERK1/2 and paxillin become phosphorylated upon stimulation with both tri- and di-nucleotides [7, 13]. Additionally, BzATP has been shown to activate downstream signals such as ERK1/2 in other cell systems [28, 29]. The signals propagated by di-nucleotides may be artifacts of saturating the system with larger than physiological concentrations [37]. Another possibility is that the signal is real and that after injury the receptors are available at a density that is unable to elicit a detectable downstream cascade. This may explain why ADP can induce migration at $10 \mu \mathrm{M}$. However, this does not take into account that high concentrations of ADP are still not able to inhibit the injury induced $\mathrm{Ca}^{2+}$ wave (data not shown). Proper signaling relies on optimal concentrations of nucleotides. At high concentrations where maximal $\mathrm{Ca}^{2+}$ release upon nucleotide exposure occurs $(>100 \mu \mathrm{M})$, epithelial cells do not migrate toward the stimuli. The desensitization of the calcium response that occurs at $100 \mu \mathrm{M}$ may explain why cell migration is minimal. In contrast, at lower concentrations where the maximal migration occurs, little desensitization occurs. This bell shape curve is not atypical and has been demonstrated to occur with nucleotide induced migration in epithelial and dendritic cells $[7,10]$.

It is likely that different signals are needed for the initial communication of an injury and the long-term need for wound healing, such as cell migration and changes in protein expression. The receptor specificity and the numerous signaling pathways provide an intricate network allowing for differential regulation of short versus long term signals. Our study provides evidence that $\mathrm{P}_{2} \mathrm{Y}_{2}$ and possibly $\mathrm{P}_{2} \mathrm{Y}_{4}$ play a role in the initial signals involved in the injury response and these receptors and other $\mathrm{P} 2$ receptors play a 
role in long term cell migration. Future studies will involve understanding the critical interactions between signaling pathways that play a role in wound healing.

\section{Acknowledgements}

This work was supported by the National Institutes of Health Grant EY06000, and departmental grants from the Massachusetts Lions Eye Research Fund, Research to Prevent Blindness, Inc., and the New England Corneal Transplant Fund.

\section{References}

1. Burnstock G. The past, present and future of purine nucleotides as signalling molecules. Neuropharmacology 1997; 36(9): 1127-39.

2. Abbracchio MP, Burnstock G. Purinergic signalling: Pathophysiological roles. Jpn J Pharmacol 1998; 78(2): 113-45.

3. Neary JT, Kang Y, Bu Y et al. Mitogenic signaling by ATP/P2Y purinergic receptors in astrocytes: Involvement of a calcium-independent protein kinase $\mathrm{C}$, extracellular signal-regulated protein kinase pathway distinct from the phosphatidylinositol-specific phospholipase C/Calcium pathway. J Neurosci 1999; 19(11): 4211-20.

4. Schwiebert EM, Zsembery A. Extracellular ATP as a signaling molecule for epithelial cells. Biochim Biophys Acta (BBA) Biomembranes 2003; 1615(1-2): 7-32.

5. Klepeis VE, Cornell-Bell A, Trinkaus-Randall V. Growth factors but not gap junctions play a role in injury-induced $\mathrm{Ca}^{2+}$ waves in epithelial cells. J Cell Sci 2001; 114(23): 4185-95.

6. Pintor J, Bautista A, Carracedo G, Peral A. UTP and diadenosine tetraphosphate accelerate wound healing in the rabbit cornea. Ophthalmic Physiol Opt 2004; 24(3): 186-93.

7. Klepeis VE, Weinger I, Kaczmarek E, Trinkaus-Randall V. P2Y receptors play a critical role in epithelial cell communication and migration. J Cell Biochem 2004; 93(6): 1115-33.

8. Pillois X, Chaulet H, Belloc I et al. Nucleotide receptors involved in UTP-induced rat arterial smooth muscle cell migration. Circ Res 2002; 90(6): 678-81.

9. Ehring GR, Szabo IL, Jones MK et al. ATP-induced $\mathrm{Ca}^{2+}$-signaling enhances rat gastric microvascular endothelial cell migration. J Physiol Pharmacol 2000; 51(4 Pt 2): 799-811.

10. Idzko M, Dichmann S, Ferrari D et al. Nucleotides induce chemotaxis and actin polymerization in immature but not mature human dendritic cells via activation of pertussis toxin-sensitive P2y receptors. Blood 2002; 100(3): 925-32.

11. Seye CI, Yu N, Jain R et al. The P2Y2 nucleotide receptor mediates UTP-induced vascular cell adhesion molecule-1 expression in coronary artery endothelial cells. J Biol Chem 2003; 278(27): 24960-65.

12. Sponsel HT, Breckon R, Anderson RJ. Adenine nucleotide and protein kinase $\mathrm{C}$ regulation of renal tubular epithelial cell wound healing. Kidney Int 1995; 48(1): 85-92.

13. Yang L, Cranson D, Trinkaus-Randall V. Cellular injury induces activation of MAPK via P2Y receptors. J Cell Biochem 2004; 91(5): 938-50.

14. Ralevic V, Burnstock G. Receptors for purines and pyrimidines Pharmacol Rev 1998; 50(3): 413-92.

15. Communi D, Janssens R, Suarez-Huerta $\mathrm{N}$ et al. Advances in signalling by extracellular nucleotides: The role and transduction mechanisms of P2Y receptors. Cell Signal 2000; 12(6): 351-60

16. Moghal N, Sternberg PW. Multiple positive and negative regulators of signaling by the EGF-receptor. Curr Opin Cell Biol 1999; 11(2) 190-6.

17. Zieske JD, Takahashi H, Hutcheon AEK, Dalbone AC. Activation of epidermal growth factor receptor during corneal epithelial migration. Invest Ophthalmol Vis Sci 2000; 41(6): 1346-55.

18. Song QH, Singh RP, Trinkaus-Randall V. Injury and EGF mediate the expression of $\alpha 6 \beta 4$ integrin subunits in corneal epithelium. J Cell Biochem 2001; 80(3): 397-414.

19. Luttrell LM, Daaka Y, Lefkowitz RJ. Regulation of tyrosine kinase cascades by G-protein-coupled receptors. Curr Opin Cell Biol 1999; 11(2): 177-83.

20. Erb L, Liu J, Ockerhausen $J$ et al. An RGD sequence in the $P 2 Y_{2}$ receptor interacts with $\alpha_{V} \beta_{3}$ integrins and is required for go-mediated signal transduction. J Cell Biol 2001; 153(3): 491-502.

21. Liu J, Liao Z, Camden J et al. Src homology 3 binding sites in the P2Y2 nucleotide receptor interact with Src and regulate activities of Src, proline-rich tyrosine kinase 2 , and growth factor receptors. J Biol Chem 2004; 279(9): 8212-8.

22. Araki-Sasaki K, Ohashi Y, Sasabe T et al. An SV40-immortalized human corneal epithelial cell line and its characterization. Invest Ophthalmol Vis Sci 1995; 36(3): 614-21.

23. Cornell-Bell AH, Finkbeiner SM, Cooper MS, Smith SJ. Glutamate induces calcium waves in cultured astrocytes: Long-range glial signaling. Science 1990; 247(4941): 470-3.

24. Klepeis VE, Weinger I, Kaczmarek E, Trinkaus-Randall V. P2Y receptors play a critical role in epithelial cell communication and migration. J Cell Biochem 2004.

25. Wilkinson GF, Purkiss JR, Boarder MR. Differential heterologous and homologous desensitization of two receptors for ATP (P2y purinoceptors and nucleotide receptors) coexisting on endothelial cells. Mol Pharmacol 1994; 45(4): 731-6.

26. Zsembery A, Boyce AT, Liang L et al. Sustained calcium entry through P2X nucleotide receptor channels in human airway epithelial cells. J Biol Chem 2003; 278(15): 13398-408.

27. Neary JT, Kang Y, Willoughby KA, Ellis EF. Activation of extracellular signal-regulated kinase by stretch-induced injury in astrocytes involves extracellular ATP and P2 purinergic receptors. J Neurosci 2003; 23(6): 2348-56.

28. Amstrup J, Novak I. P2X $\mathrm{X}_{7}$ receptor activates extracellular signalregulated kinases ERK1 and ERK2 independently of $\mathrm{Ca}^{2+}$ influx. Biochem J 2003; 374(Pt 1): 51-61.

29. Bradford MD, Soltoff SP. P2X $X_{7}$ receptors activate protein kinase D and p42/p44 mitogen-activated protein kinase (MAPK) downstream of protein kinase C. Biochem J 2002; 366(Pt 3): 745-55.

30. Santiago-Pérez LI, Flores RV, Santos-Berríos C et al. P2 $\mathrm{Y}_{2}$ nucleotide receptor signaling in human monocytic cells: Activation, desensitization and coupling to mitogen-activated protein kinases. J Cell Physiol 2001; 187(2): 196-208.

31. Soltoff SP. Related adhesion focal tyrosine kinase and the epidermal growth factor receptor mediate the stimulation of mitogen-activated protein kinase by the G-protein-coupled $\mathrm{P} 2 \mathrm{Y}_{2}$ receptor. J Biol Chem 1998; 273(36): 23110-7.

32. Milenkovic I, Weick M, Wiedemann P et al. P2Y receptor-mediated stimulation of muller glial cell DNA synthesis: Dependence on EGF and PDGF receptor transactivation. Invest Ophthalmol Vis Sci 2003; 44(3): 1211-20.

33. Prenzel N, Zwick E, Daub H et al. EGF receptor transactivation by G-protein-coupled receptors requires metalloproteinase cleavage of proHB-EGF. Nature 1999; 402(6764): 884-8.

34. Schafer B, Gschwind A, Ullrich A. Multiple G-protein-coupled receptor signals converge on the epidermal growth factor receptor to promote migration and invasion. Oncogene 2004; 23(4): 991-9.

35. Andreev J, Galisteo ML, Kranenburg O et al. Src and Pyk2 mediate G-protein-coupled receptor activation of Epidermal Growth Factor Receptor (EGFR) but are not required for coupling to the MitogenActivated Protein (MAP) kinase signaling cascade. J Biol Chem 2001; 276(23): 20130-5.

36. Luttrell LM, Hawes BE, van Biesen $\mathrm{T}$ et al. Role of c-Src tyrosine kinase in $G$ protein-coupled receptor and $G \beta \gamma$ subunit-mediated activation of mitogen-activated protein kinases. J Biol Chem 1996; 271(32): 19443-50.

37. Traut TW. Physiological concentrations of purines and pyrimidines. Mol Cell Biochem 1994; 140(1): 1-22. 